\title{
Pharmacological profile of a new orally active growth hormone secretagogue, SM-130686
}

\author{
J Nagamine, R Nagata, H Seki, N Nomura-Akimaru, Y Ueki, \\ K Kumagai, $\mathbf{M}$ Taiji and $\mathbf{H}$ Noguchi
}

Sumitomo Pharmaceuticals Co. Ltd, Discovery Research Laboratories II, 1-98 Kasugade Naka 3-chome, Konohana-ku, Osaka 554-0022, Japan

(Requests for offprints should be addressed to M Taiji, Sumitomo Pharmaceuticals Co. Ltd, Discovery Research Laboratories II, 3-1-98 Kasugadenaka, Konohana-ku, Osaka 554-0022, Japan; Email: taiji@sumitomopharm.co.jp)

\begin{abstract}
SM-130686, an oxindole derivative, is a novel orally active GH secretagogue (GHS) which is structurally distinct from previously reported GHSs such as MK-677, NN703 and hexarelin. SM-130686 stimulates GH release from cultured rat pituitary cells in a dose-dependent manner. Half-maximum stimulation was observed at a concentration of $6 \cdot 3 \pm 3 \cdot 4 \mathrm{nM}$. SM-130686-induced GH release was inhibited by a GHS antagonist, but not by a GHreleasing hormone antagonist. SM-130686 dosedependently inhibited the binding of radiolabeled ligand, ${ }^{35} \mathrm{~S}-\mathrm{MK}-677$, to human GHS receptor $1 \mathrm{a}\left(\mathrm{IC}_{50}=1.2 \mathrm{nM}\right)$. This indicates that SM-130686 stimulates GH release through the GHS receptor. The effect of a single oral administration of SM-130686 on GH release in pentobarbital-anesthetized rats was studied. After treatment with $10 \mathrm{mg} / \mathrm{kg}$ SM-130686, plasma GH concentrations measured by radioimmunoassay significantly increased, reaching a peak at 20-45 min, and remained above baseline during the experimental period $(60 \mathrm{~min})$. The anabolic effect of repetitive SM-130686 admin-
\end{abstract}

istration was studied in rats. Rats received $10 \mathrm{mg} / \mathrm{kg}$ SM-130686 orally twice a day and were weighed every day for 9 days. At day 9 there was a significant increase in both the body weight and the fat free mass $(19 \cdot 5 \pm 2 \cdot 1$ and $18.1 \pm 7.5 \mathrm{~g}$ respectively). Serum IGF-I concentration was also significantly elevated $6 \mathrm{~h}$ after the last dose of SM-130686. An endogenous GHS ligand for the GHS receptor has recently been identified from stomach extract and designated as ghrelin. The GH-releasing activity in vitro relative to ghrelin $(100 \%)$ was about $52 \%$ for SM-130686. It is likely that SM-130686 is a partial agonist for the GHS receptor.

In summary, we describe here an orally active GHS, SM-130686, which acts through the GHS receptor. Repetitive administration of SM-130686 to rats, similar to repetitive administration of $\mathrm{GH}$, significantly increased the fat free mass by an amount almost equal to the gain in body weight.

Journal of Endocrinology (2001) 171, 481-489

\section{Introduction}

The secretion of growth hormone $(\mathrm{GH})$ is regulated by the neuroendocrine control system like other anterior pituitary hormones. Two main hypothalamic factors, GH-releasing hormone (GHRH) and somatostatin, are known to be involved as positive and negative regulators, respectively, in GH release (Frohman et al. 1992). After GH-releasing peptide (GHRP)-6 and its analogues were found to enhance GH secretion as well as GHRH, a number of new chemical entities with similar characteristics were successfully synthesized. The peptidic factors with GHreleasing activity include GHRP-1, GHRP-2, GHRP-6 and hexarelin; other non-peptidic compounds include L-692,429 and MK-677 (Camanni et al. 1998). Among these GH secretagogues (GHSs), MK-677 has been reported to show good oral bioavailability. In addition, chemically synthesized GHSs including GHRP-6 and
MK-677 have been reported to show highly potent GHreleasing activity in several species including humans (Walker et al. 1990, Bowers et al. 1992, Hartman et al. 1992, Chapman et al. 1996).

Using the affinity of MK-677 as a clue, a novel GHS receptor was cloned by Howard et al. (1996). This receptor is expressed in various kinds of tissues: pituitary, hypothalamus and other areas of the central nervous system (CNS) (Guan et al. 1997). Recently, an endogenous GHS ligand for the GHS receptor has been identified from stomach extract and designated as ghrelin, an acylated peptide of 28 amino acids (Kojima et al. 1999). Ghrelin mRNA is present in the hypothalamus arcuate nucleus and stomach. Intravenous injection of ghrelin stimulated $\mathrm{GH}$ release, suggesting that $\mathrm{GH}$ secretion in the pituitary may be regulated not only by ghrelin expressed in the hypothalamus, but also by ghrelin released from the stomach. Since ghrelin mRNA was reported most abundantly in the 


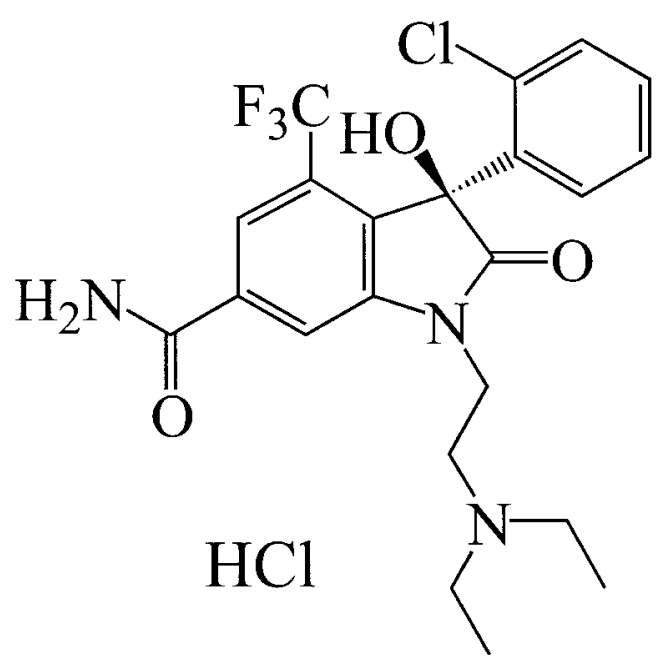

Figure 1 Structure of SM-130686: (S)-1-(2-diethylaminoethyl)-4trifluoromethyl-6-carbamoyl-3-hydroxy-3-(2-chrolophenyl) oxindole.

stomach, it is very likely that ghrelin has some other physiological functions (Dieguez \& Casanueva 2000).

We screened our chemical library for a new GHS using a rat pituitary cell culture system and found an oxindole derivative that showed GH-releasing activity. Modification of this oxindole derivative led to an entirely new class of non-peptidic GHSs represented by SM-130686 (Fig. 1) (Tokunaga et al. 2001), which are structurally different from GHRP-6, hexarelin, MK-677 and NN703 (Hansen et al. 1999). Here we report the pharmacological profile of a new type of GHS, SM-130686.

\section{Materials and Methods}

\section{Animals}

Adult male Wistar/ST rats and female F344/N rats were purchased from SLC Japan Inc., Sizuoka, Japan. All rats were kept in a temperature $\left(23 \pm 2{ }^{\circ} \mathrm{C}\right)$ - and humidity $(55 \pm 10 \%)$-controlled room with lights on between 0800 and $2000 \mathrm{~h}$. Water and standard laboratory chow (CE-2; Cler Japan, Inc., Tokyo, Japan) were freely available. All animal experiments were conducted according to the guidelines of the Sumitomo Pharmaceuticals Committee on Animal Research.

\section{Materials}

Horse and fetal calf sera, non-essential amino acids (100fold concentrated), penicillin-streptomycin solution and Hank's balanced salt solution (HBSS) were purchased from Gibco, New York, NY, USA. Dulbecco's modified Eagle's medium (DMEM) was from Iwaki, Tokyo, Japan. Collagenase was from Worthington Biochemical,
Lakewood, NJ, USA. DNase type I was from Sigma, St Louis, MO, USA. EDTA, HEPES, $\mathrm{NaCl}, \mathrm{KCl}$, $\mathrm{Na}_{2} \mathrm{HPO}_{4}, \mathrm{CaCl}_{2}$ and dimethyl sulfide were from Nacalai Tesque, Kyoto, Japan. Ghrelin was synthesized using the method previously reported by Tschöp et al. (2000).

\section{Rat pituitary cell assay}

Anterior pituitaries were obtained from 7-week-old male Wistar/ST rats. The tissue was washed three times with HBSS, cut into small pieces and transferred to the isolation buffer $(100 \mu \mathrm{l} /$ lobe $)$ containing $0 \cdot 8 \%$ collagenase and $0 \cdot 2 \%$ DNase type I. The mixture was incubated for less than $25 \mathrm{~min}$ at $37^{\circ} \mathrm{C}$. The cells were collected and washed three times with the culture medium; DMEM was supplemented with $5 \%$ horse serum, $2 \cdot 5 \%$ fetal calf serum, $1 \%$ non-essential amino acids, $1 \%$ penicillin and 1\% streptomycin. Cells were resuspended in the above medium and brought to a density of $1.0 \times 10^{5}$ cells $/ \mathrm{ml}$. The cells $(200 \mu \mathrm{l} /$ well) were seeded onto a 96-well plate (Nunc, Roskilde, Denmark) and cultured for 5 days at $37^{\circ} \mathrm{C}$ under $5 \% \mathrm{CO}_{2}$.

Following the culture period the cells were washed once with the stimulation buffer (culture medium containing $25 \mathrm{mM}$ HEPES, $\mathrm{pH} \mathrm{7.3)}$ and then incubated for $90 \mathrm{~min}$ at $37^{\circ} \mathrm{C}$ under $5 \% \mathrm{CO}_{2}$. This buffer was then replaced with a fresh stimulation buffer containing SM-130686 followed by incubation for $15 \mathrm{~min}$ at $37^{\circ} \mathrm{C}$ under $5 \% \mathrm{CO}_{2}$. The medium was collected and assayed for $\mathrm{GH}$ concentration. To study the effect of antagonists, the cells were incubated with an antagonist (final additive concentration $10 \mu \mathrm{M}$ ) before the SM-130686 solution was added.

\section{GHS-binding activity}

Crude membranes were isolated from $\mathrm{CHO}$ cells stably expressing the human GHS receptor 1a. These were suspended in binding buffer $(50 \mathrm{mM}$ Tris- $\mathrm{HCl}, 10 \mathrm{mM}$ $\mathrm{MgCl}_{2}, 2.5 \mathrm{mM}$ EDTA, $\left.\mathrm{pH} 7.4\right)$ to a concentration of $1 \mathrm{mg}$ protein $/ \mathrm{ml}$. These membranes $(25 \mu \mathrm{g}$ protein/well) were mixed with ${ }^{35} \mathrm{~S}-\mathrm{MK}-677$ (100 000 d.p.m./well), with or without different concentrations $(0 \cdot 1-100 \mathrm{nM})$ of SM-130686 and binding buffer up to a total volume of $250 \mu$ l. Non-specific binding was obtained by adding $500 \mathrm{nM}$ cold MK-677. The membranes were incubated at $25{ }^{\circ} \mathrm{C}$ for $60 \mathrm{~min}$, and bound radioligand was separated from free radioligand by washing with binding buffer through a GF/B filter (Perkin Elmer, Boston, MA, USA). The radioactivity on the filters was counted in a scintillation counter (Perkin Elmer).

\section{GH response of SM-130686 in anesthetized rats}

Adult male rats (8 weeks old, 250-300 g) were anesthetized by intraperitoneal injection of pentobarbital; a catheter was inserted in the right jugular vein for blood 
sampling and drug administration. Ten minutes after surgery, blood samples were withdrawn and different doses of SM-130686 were injected intravenously or administered orally to each animal. Blood samples $(200 \mu \mathrm{l})$ were drawn at specified times and collected into a tube containing $5 \mathrm{U}(50 \mu \mathrm{l})$ heparin. Plasma $(50 \mu \mathrm{l})$ was separated by centrifugation and mixed with $200 \mu \mathrm{l}$ radioimmunoassay (RIA) buffer. The samples were stored at $-40{ }^{\circ} \mathrm{C}$ until being assayed for rat $\mathrm{GH}$.

\section{GH response of SM-130686 in conscious rats}

Twenty-seven adult male rats (16 weeks old, 350-400 g) were prepared 7 days before the experiment with indwelling right jugular catheters under pentobarbital anesthesia. After surgery, water was administered orally to the animals to minimize treatment stress. Catheters were kept patent by flushing with $200 \mu \mathrm{l}$ heparinized saline $(50 \mathrm{U} / \mathrm{ml})$ every day. At $0830 \mathrm{~h}$ on the day of the experiment, all lines were fitted with extensions filled with heparin. At $1000 \mathrm{~h}$, baseline blood samples were drawn and SM$130686(10 \mathrm{mg} / \mathrm{kg})$ was administered orally to each rat. Blood samples $(100 \mu \mathrm{l})$ were drawn every $20 \mathrm{~min}$ after administration and collected into a tube containing $5 \mathrm{U}$ $(50 \mu \mathrm{l})$ heparin. Plasma $(50 \mu \mathrm{l})$ was separated by centrifugation and mixed with $200 \mu \mathrm{l}$ RIA buffer. The samples were stored at $-40{ }^{\circ} \mathrm{C}$ until being assayed for the concentration of rat $\mathrm{GH}$. The blood cells were resuspended in $1 \mathrm{ml}$ saline and returned to the animal after experimentation.

\section{Anabolic effects of SM-130686 in rats}

Female 11-week-old F344/N rats were used in this study. One day before experimentation, all rats were weighed and fat free mass was measured by whole body bioelectrical impedance analysis with a small animal body composition analyzer (SA-2; EM-SCAN Inc., Springfield, IL, USA) (Morbach \& Brans 1992). Rats were randomly allocated according to the above two parameters to three treatment groups, each containing six animals. The drug was orally administered twice a day to each rat (1000 h and $1600 \mathrm{~h}$ ) for 9 days (starting from day 0 ). The rats were weighed every morning just before administration of the drug, and the fat free mass was measured on day 9.

Six hours (1600 h) after the last dose on day 9, rats were decapitated and trunk blood was collected for hormone analysis. The plasma was separated by centrifugation and stored at $-40{ }^{\circ} \mathrm{C}$ until being assayed for rat insulin-like growth factor-I (IGF-I) concentration.

\section{GH and IGF-I assays}

Rat GH concentration was measured by the doubleantibody RIA method. Rabbit anti-rat GH antibody was purchased from Biogenesis, Poole, Dorset, UK. GH concentration was expressed in terms of the NIH-RP-2 standard. The intra- and interassay coefficients of variation were below $11 \%$ and $13 \%$ with a $1 \mathrm{ng} / \mathrm{ml}$ limit of quantitation. The IGF-I concentration was measured based on acid-ethanol extraction using a commercial kit (DSL, Austin, TX, USA). The intra- and interassay coefficients of variation were below $6.1 \%$ and $9.7 \%$ with a $3 \mathrm{ng} / \mathrm{ml}$ limit of quantitation.

\section{Calculations}

Using the $\mathrm{EC}_{50}$ value of SM-130686, the potency was calculated as the concentration inducing half-maximal stimulation with the following scheme $(\mathrm{GH}$ content $=$ Emax $\times$ concentration of SM-130686/(EC $\mathrm{E}_{50}+$ concentration of SM-130686)+basal GH content). Area under the concentration (AUC) in the in vivo study was calculated using the trapezoidal rule. All data are reported as means \pm S.D. except for the $\mathrm{EC}_{50}$ and Emax values of $\mathrm{GH}$ release in the in vitro study (means \pm s.E.M.) and $\mathrm{GH}$ release in the in vivo study. All statistical comparisons were performed using SAS (version $6 \cdot 12$; Cray, NC, USA).

\section{Results}

\section{GH-releasing activity of SM-130686 through the GHS receptor}

The GH-releasing activity of SM-130686 was studied using cultured rat pituitary cells. GH concentration in the culture medium was determined by RIA $15 \mathrm{~min}$ after treatment with SM-130686. SM-130686 enhanced GH release dose-dependently with $\mathrm{EC}_{50}$ values of $6 \cdot 3 \pm$ $3.4 \mathrm{nM}$ (means \pm s.E.M.) in five different experiments with rat pituitary primary culture (Fig. 2A). To evaluate the pharmacological properties of SM-130686, we investigated the effects of concomitant treatment of GHS antagonist ([D-Arg $\left.{ }^{1}, \mathrm{D}-\mathrm{Phe}^{5}, \mathrm{D}-\operatorname{Trp}^{7,9}, \mathrm{Leu}^{11}\right]$-substance P) or GHRH antagonist ([N-acetyl-Try $\left.{ }^{1}, \mathrm{D}-\mathrm{Arg}^{2}\right]-$ hGHRH(1-29) $\mathrm{NH}_{2}$ ) with SM-130686 on GH-releasing activity (Cheng et al. 1997). As shown in Fig. 2B, GHS antagonist inhibited the GH-releasing activity of SM130686, whereas the GHRH antagonist had neither an additive nor a synergistic effect. These results suggested that SM-130686 increases GH release by acting on the GHS receptor.

We therefore decided to evaluate the binding affinity of SM-130686 for the GHS receptor which was originally identified as MK-677-binding protein and recently found to be the receptor for an endogenous ligand called ghrelin. As shown in Fig. 3, SM-130686 dose-dependently inhibited the binding of radioisotope-labeled ligand, ${ }^{35} \mathrm{~S}-\mathrm{MK}-$ 677, to recombinant human GHS receptor 1a that was stably expressed in $\mathrm{CHO}$ cells. The $\mathrm{IC}_{50}$ value of 

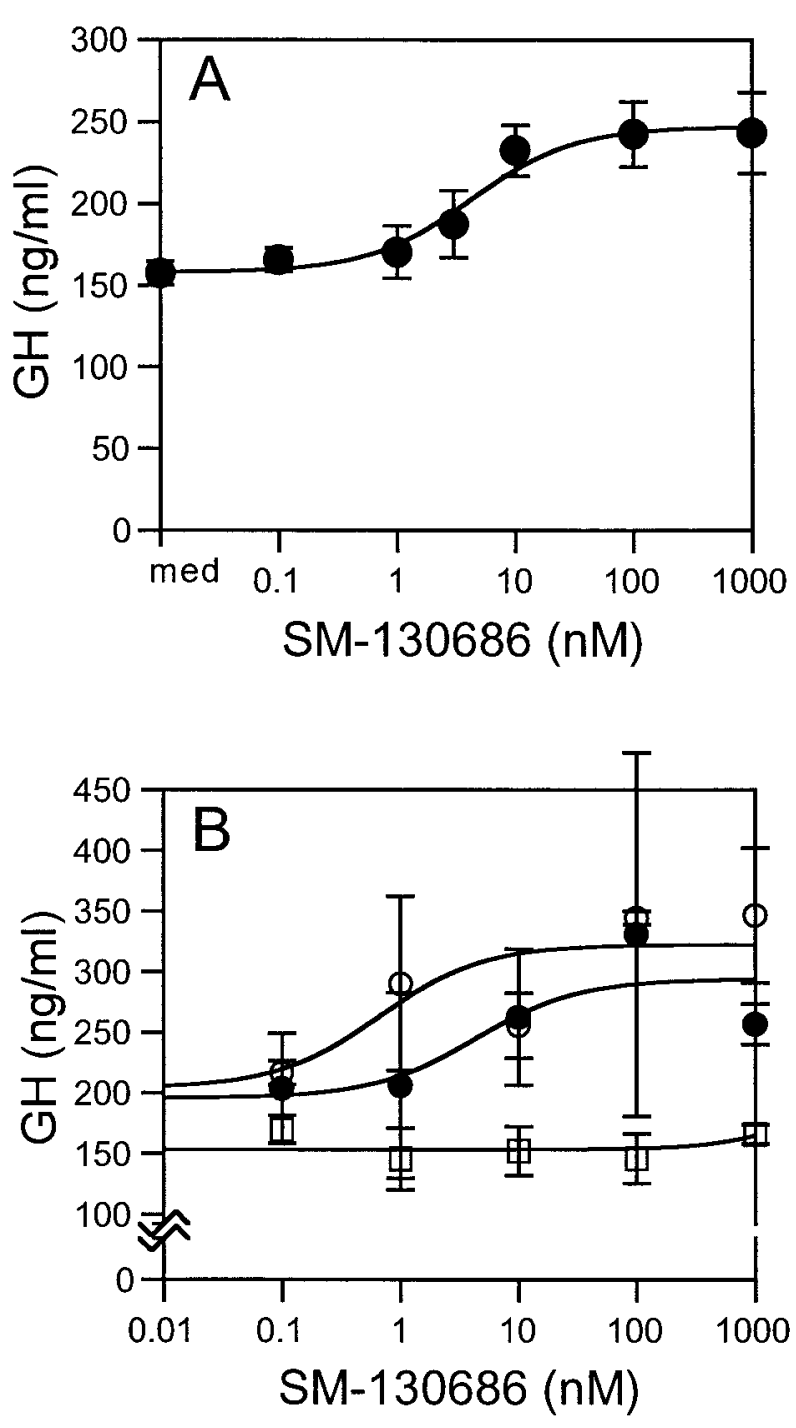

Figure 2 (A) Dose-response relationship in $\mathrm{GH}$ release from rat pituitary cells induced by SM-130686. med, medium; (B) Inhibition of SM-130686-stimulated GH release () by [D-Arg ${ }^{1}, \mathrm{D}-\mathrm{Phe}^{5}, \mathrm{D}-\operatorname{Trp}^{7,9}$, Leu $\left.{ }^{11}\right]$-substance $\mathrm{P}$ (GHS antagonist, $\square$ ), but not by [N-acetylTry $^{1}$, D-Arg $^{2}$ ]-hGHRH(1-29) $\mathrm{NH}_{2}$ (GHRH antagonist, O). GHS or $\mathrm{GHRH}$ antagonist concentration was $10 \mu \mathrm{M}$. Data are means \pm S.D. $(n=3)$.

SM-130686 was calculated to be $1 \cdot 2 \pm 0 \cdot 2 \mathrm{nM}$ in this assay. In order to investigate whether SM-130686 was specifically bound to the GHS receptor or not, in vitro binding activities of SM-130686 were extensively studied on more than 50 other receptors, including opiate, sigma, bradykinin, muscarine, neurokinin, benzodiazepine, serotonin, dopamine, gamma aminobutyric acid, GHRH and somatostatin receptors. The $\mathrm{IC}_{50}$ values of SM-130686 for these receptors were more than $1 \mu \mathrm{M}$ (data not shown) indicating that SM-130686 has specific and high affinity for the GHS receptor.

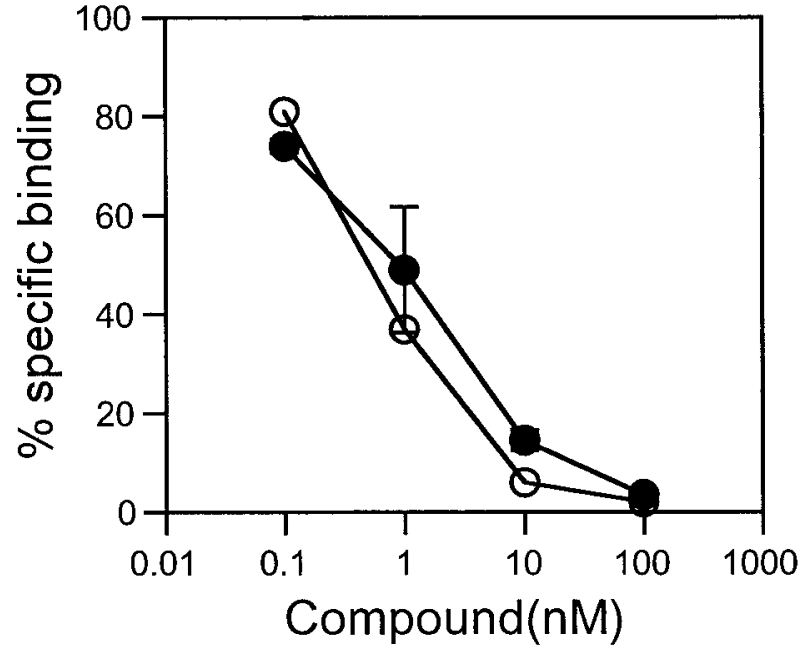

Figure 3 Inhibition of ${ }^{35} \mathrm{~S}-\mathrm{MK}-677$ binding to $\mathrm{CHO}$ membranes expressing the human GHS receptor by MK-677(O) and SM-130686 (@). Results are means \pm S.D. $(n=2)$.

\section{Effect of SM-130686 administration on GH release in pentobarbital-anesthetized rats}

To study GH-releasing activity in vivo, SM-130686 was intravenously injected into pentobarbital-anesthetized rats through a catheter inserted into the right jugular vein. After intravenous injections of 1 and $3 \mathrm{mg} / \mathrm{kg}$ SM130686, the plasma GH concentrations of each group of rats given SM-130686 reached a peak at 4 min and returned to baseline by $16 \mathrm{~min}$ (Fig. 4A). The peak plasma $\mathrm{GH}$ concentration increased in a dose-dependent manner.

We investigated the pharmacokinetic profile of SM130686 in rats after oral administration. Bioavailability was found to be $27 \cdot 6 \%$, indicating that SM-130686 is an orally active GHS. It was therefore decided to investigate the effect of oral administration of SM-130686 on GH release in pentobarbital-anesthetized rats. After oral administration of 1,3 and $10 \mathrm{mg} / \mathrm{kg}$ SM-130686, the peak plasma GH concentrations increased in a dose-dependent manner and remained above baseline during the experimental period of $60 \mathrm{~min}$ (Fig. 4B).

\section{GH response to oral administration of SM-130686 in conscious male rats}

Following the studies using anesthetized rats, the efficacy of SM-130686 oral administration was further assessed by monitoring GH-releasing activity in conscious rats. Rats were implanted with cannulae for blood sampling into the right jugular veins under pentobarbital anesthesia 7 days before the SM-130686 administration experiment. After a single oral administration of SM-130686, plasma $\mathrm{GH}$ concentration peaked within $3 \mathrm{~h}$ in all four rats (Fig. 5 lower panel). AUC and Cmax values for the plasma 

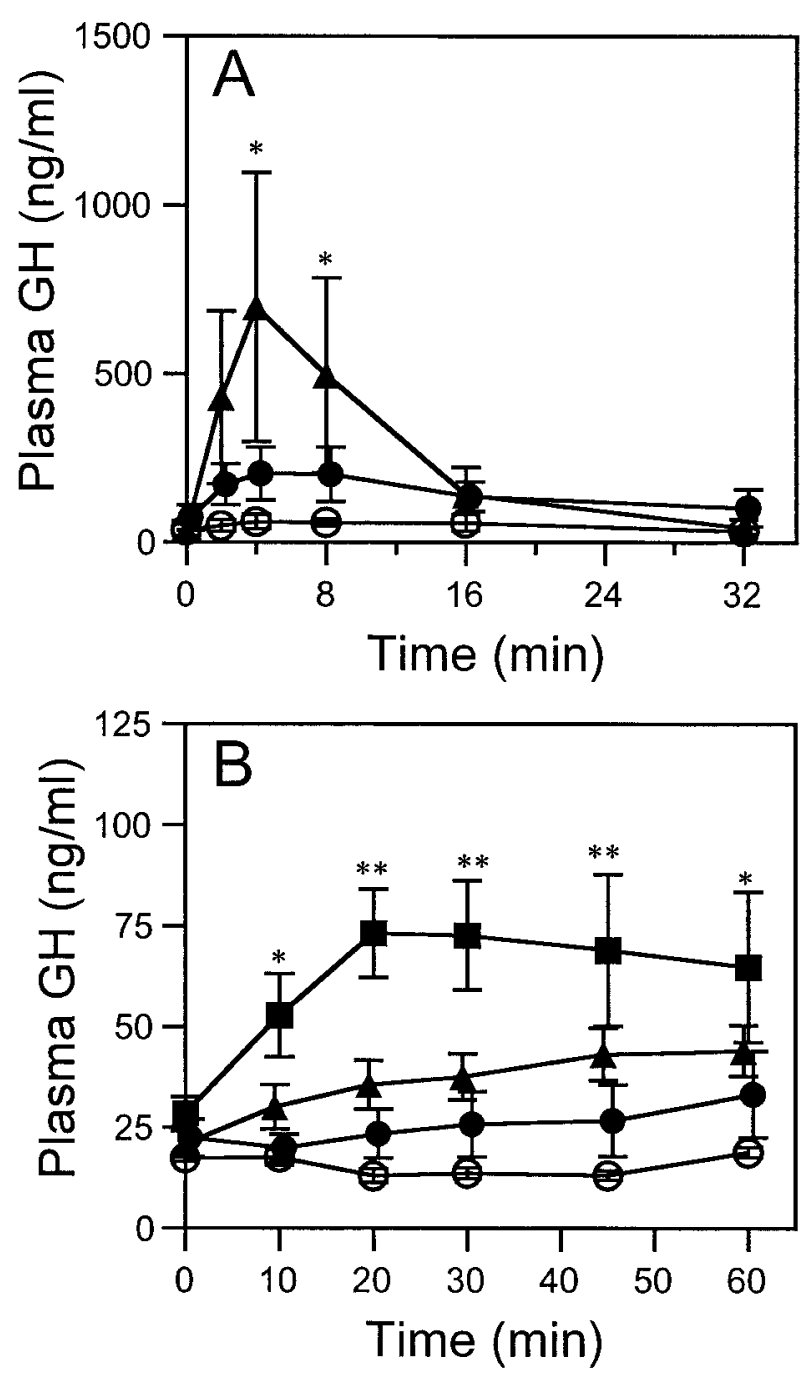

Figure 4 (A) Time-course of plasma $\mathrm{GH}$ levels in male pentobarbital-anesthetized rats after intravenous injection of SM-130686: $0 \mathrm{mg} / \mathrm{kg}(\bigcirc, n=3), 1 \mathrm{mg} / \mathrm{kg}(\bullet, n=4)$ and $3 \mathrm{mg} / \mathrm{kg}$ $(\boldsymbol{\Delta}, n=3)$. (B) Time-course of plasma GH levels in male pentobarbital-anesthetized rats after oral administration of SM-130686: $10 \mathrm{mg} / \mathrm{kg}(\boldsymbol{\square}, n=5), 3 \mathrm{mg} / \mathrm{kg}(\boldsymbol{\Lambda}, n=5), 1 \mathrm{mg} / \mathrm{kg}$ $n=5)$ and $0 \mathrm{mg} / \mathrm{kg}(O, n=4)$. Data are means \pm S.E.M.. ${ }^{*} P<0 \cdot 025$, ${ }^{* *} P<0.005$ by the Williams test (Williams 1972) (vs group treated with $0 \mathrm{mg} / \mathrm{kg}$ ).

$\mathrm{GH}$ concentration during the first $3 \mathrm{~h}$ after $10 \mathrm{mg} / \mathrm{kg}$ SM-130686 administration increased compared with vehicle-treated rats (Table 1).

\section{Anabolic effect of SM-130686 in normal female rats}

The results on GH-releasing activity of SM-130686 in vitro and in vivo encouraged us to investigate further the efficacy of repetitive administration. SM-130686 was orally administered to normal female rats every day for 9 days (starting at day 0 ). The rats were weighed every morning just before administration of the drug, and the fat free mass which was mainly composed of muscle, bone and water, was measured by the bioelectrical impedance method at days -1 and 9. Treatment with $6 \mathrm{mg} / \mathrm{kg}$ SM-130686 per day did not significantly affect the body weight gain in rats (Fig. 6). However, rats given $20 \mathrm{mg} / \mathrm{kg} \mathrm{SM}-130686$ per day showed a significantly higher body weight gain at day 1 compared with vehicle-treated rats. This enhanced body weight gain in the group given $20 \mathrm{mg} / \mathrm{kg}$ per day continued with no apparent sign of attenuation during the experimental period of giving repetitive daily administration. At the end of the treatment (day 9), the gain in fat free mass significantly increased in the SM-130686treated $(20 \mathrm{mg} / \mathrm{kg}$ per day) rats (Table 2). Administration of 6 and $20 \mathrm{mg} / \mathrm{kg} \mathrm{SM}-130686$ per day increased the plasma IGF-I levels in a dose-dependent manner $6 \mathrm{~h}$ after the last administration (day 9) (Table 2).

GH-releasing activity of SM-130686 in vitro compared with ghrelin, an endogenous ligand for the GHS receptor

Ghrelin enhanced GH release dose dependently with $\mathrm{EC}_{50}$ values of $2.4 \pm 0.5 \mathrm{nM}$ (means \pm s.E.M.) in three experiments of cultured rat primary pituitary cells (Fig. 7). The Emax of SM-130686 was $52 \pm 12 \%$ relative to that of ghrelin in the three experiments, indicating that SM130686 might be a partial agonist for the GHS receptor.

\section{Discussion}

Among the peptidic and non-peptidic chemical compounds with GH-releasing activity, MK-677 has been reported to show good oral bioavailability (Patchett et al. 1995). In this study we have demonstrated a new class of orally active GHSs represented by SM-130686. The $\mathrm{EC}_{50}$ of SM-130686 in enhancing GH release was $6 \cdot 3 \pm 3 \cdot 4 \mathrm{nM}$, nearly as potent as MK-677 with an $\mathrm{EC}_{50}$ value of $2.7 \pm 0.9 \mathrm{nM}$ as measured in our experiment. The result of a binding assay using ${ }^{35} \mathrm{~S}-\mathrm{MK}-677$ as a radioligand also showed that the affinity of SM-130686 with the human GHS receptor $1 \mathrm{a}\left(\mathrm{IC}_{50}=1.2 \mathrm{nM}\right)$ was similar to MK-677 $\left(\mathrm{IC}_{50}=0.5 \mathrm{nM}\right)$. The biological activity of SM130686 in enhancing GH release was blocked by the GHS antagonist, but not by the GHRH antagonist in rat pituitary cells. These pharmacological properties indicate that our SM-130686 enhances GH release by acting on the GHS receptor.

Physiologically, GH is secreted in a pulsatile fashion (Frohman et al. 1992, Müller et al. 1999). Since the dosing of exogenous GH (once daily or less) does not mimic the normal GH secretion profile, a more natural treatment needs to be developed for patients with GH deficiency. Furthermore, it is known that plasma concentrations of $\mathrm{GH}$ and IGF-I wane with aging in the human, and mean 

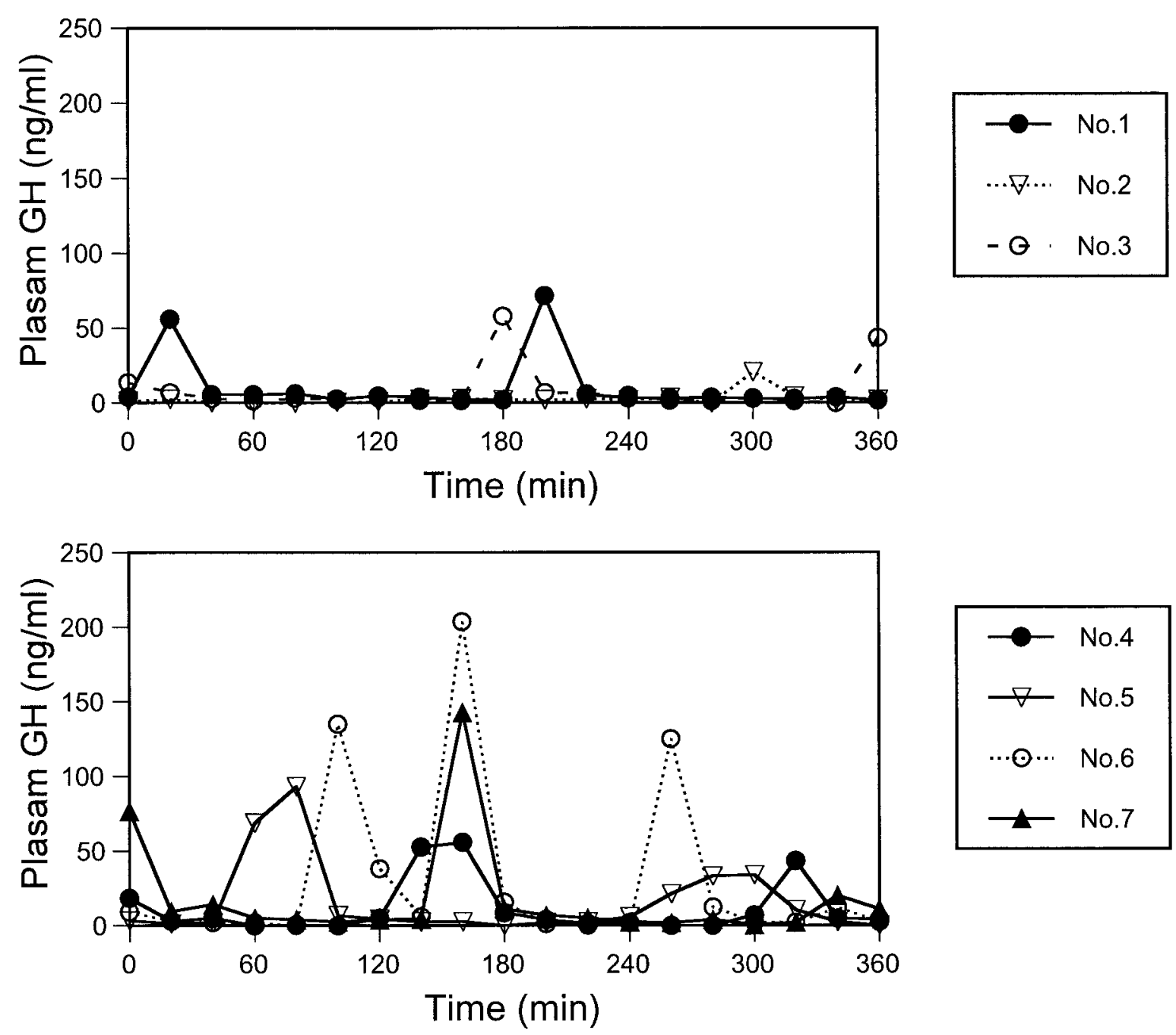

Figure $5 \mathrm{GH}$ response after oral administration of SM-130686 (lower panel, $n=4$ ), or vehicle (upper panel, $n=3$ ) in individual conscious male rats. SM-130686 (10 mg/kg) was administered at $1000 \mathrm{~h}(0 \mathrm{~min})$. Blood was withdrawn at 0 min before and every $20 \mathrm{~min}$ after administration for $360 \mathrm{~min}$.

Table $1 \mathrm{GH}$ response after oral administration of SM-130686 in conscious male rats. Values are for individual rats ${ }^{\mathrm{a}}$ or means \pm S.D.

\begin{tabular}{|c|c|c|c|c|c|}
\hline & \multirow{2}{*}{$\begin{array}{l}\operatorname{Tmax} \\
(\min )^{a}\end{array}$} & \multicolumn{2}{|c|}{ Cmax (ng/ml) } & \multicolumn{2}{|c|}{ AUC $(\mathrm{ng} / \mathrm{ml} \cdot \mathrm{h})$} \\
\hline & & $0-360 \mathrm{~min}$ & $180-360 \mathrm{~min}$ & $0-360 \mathrm{~min}$ & $180-360 \mathrm{~min}$ \\
\hline $\begin{array}{l}\text { Treatment } \\
\text { Vehicle }(n=3)\end{array}$ & $180,200,300$ & $50 \pm 26$ & $50 \pm 26$ & $42 \pm 23$ & $24 \pm 10$ \\
\hline $\begin{array}{l}\text { SM-130686 } \\
\qquad(20 \mathrm{mg} / \mathrm{kg} \text { per day })(n=4)\end{array}$ & $80,160,160,160$ & $124 \pm 64$ & $56 \pm 47$ & $112 \pm 53$ & $33 \pm 17$ \\
\hline
\end{tabular}

plasma GH concentration in people over 60 years old is approximately one third to one half that of young adults (Rudman 1985, Zadik et al. 1985, Ho et al. 1987, Iranmanesh et al. 1991). Notably, daily oral administration of MK-677 increases plasma GH concentration in healthy elderly subjects and also increases their plasma IGF-I concentration to the normal range of young adults (Chapman et al. 1996). Further, the enhancement of pulsatile GH release by MK-677 has been reported to be due to an increase of pulse height (=mass of GH secreted per pulse) rather than the number of pulses in plasma GH secretion profiles. Similarly, the present study 


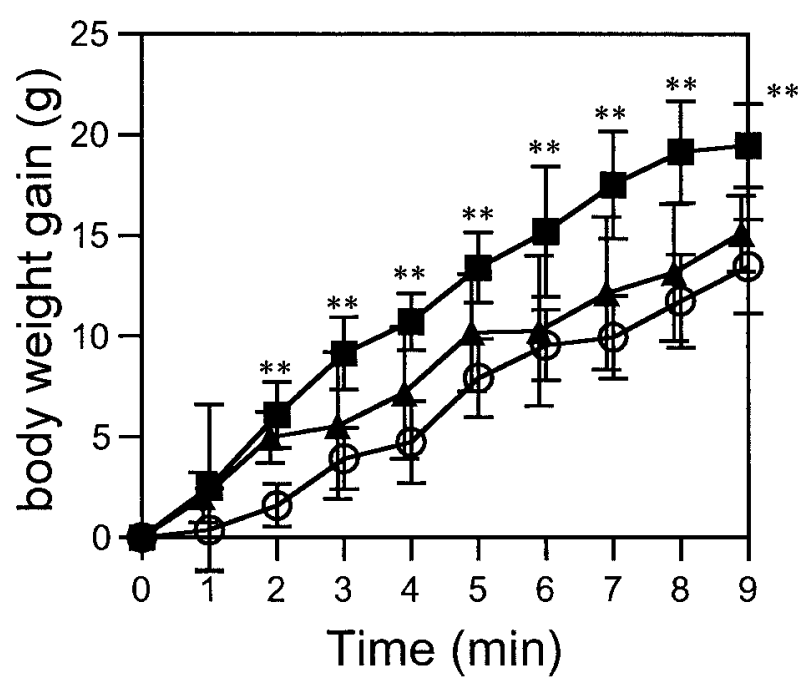

Figure 6 Time-course of body weight gain in 11-week-old female rats given oral administration of different doses of SM-130686: $0 \mathrm{mg} / \mathrm{kg}$ per day $(\bigcirc), 6 \mathrm{mg} / \mathrm{kg}$ per day $(\boldsymbol{\Delta})$ and $20 \mathrm{mg} / \mathrm{kg}$ per day (ם). SM-130686 was administered twice a day every day for 9 days. Data are means \pm S.D. $(n=6) .{ }^{* *} P<0.005$ by the Williams test (Williams 1972) (vs group treated with $0 \mathrm{mg} / \mathrm{kg}$ ).

demonstrated that SM-130686 enhanced pulsatile GH secretion in conscious male rats. These characteristics indicate that GHSs might lead to a more desirable treatment not only for GH deficiency but also for healthy elderly subjects.

GH plays a critical role in a variety of physiological processes, including longitudinal bone growth and body metabolism. With regards to body metabolism, it has been shown previously that $\mathrm{GH}$ possesses anabolic, lipolytic and anti-natriuretic actions, and thus affects body composition (Møller et al. 1995). The effects of GH on body composition in mature female rats have been investigated using a two-compartment model of fat mass and fat free mass (mainly composed of muscle, bone and water). Results showed that body weight gain after $\mathrm{GH}$ treatment was largely due to fat free mass accretion (Azain et al. 1995). It has also been reported that peptidic GHSs such as GHRP-6 (Bowers et al. 1984), G7039 (McDowell et al.

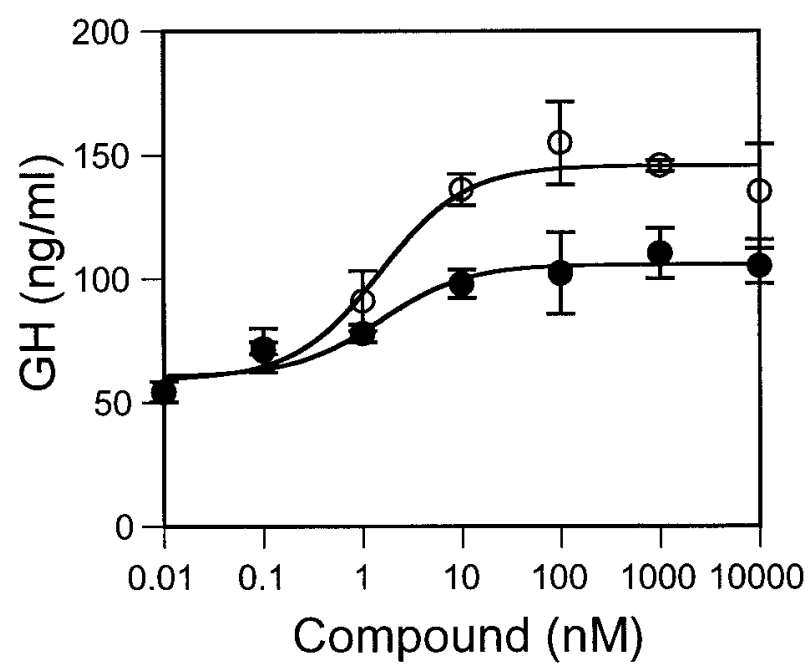

Figure 7 Dose-response relationship of $\mathrm{GH}$ release from rat pituitary cells induced by ghrelin $(\bigcirc)$ or SM-130686 ( ). Data are means \pm S.D. $(n=3)$.

1995) and NN703 (Hansen et al. 1999) significantly stimulate body weight gain in female rats after daily administration for more than 7 days. Peptidic GHSs have been known to stimulate food intake, possibly through direct action on the CNS (Locke et al. 1995, Okada et al. 1996), and thus the increase in body weight gain is partly due to fat mass gain.

Recently, an endogenous GHS ligand for the GHS receptor has been identified and designated as ghrelin (Kojima et al. 1999). Ghrelin increases body weight gain by stimulating fat mass gain without any change in fat free mass in mice (Tschöp et al. 2000). Thus, it may be that ghrelin itself enhances glucose catabolism and reduces fat utilization in mice and rats. Similar data were observed after administration of KP-102, a peptidic GHS, indicating a GHS/ghrelin receptor-mediated mechanism (Tschöp et al. 2000). In the present study, repetitive administration of SM-130686 significantly increased the fat free mass by almost the same amount as the gain in body weight. Further, we preliminarily confirmed that defatted dry mass (composed of body protein and minerals etc.) of rats given

Table 2 Effect of SM-130686 on body composition in female rats. Values are means \pm S.D. of six rats per group

\begin{tabular}{|c|c|c|c|}
\hline & \multicolumn{3}{|c|}{ SM-130686 (mg/kg per day) } \\
\hline & 0 & 6 & 20 \\
\hline \multicolumn{4}{|l|}{ Parameter } \\
\hline Weight gain $(\mathrm{g})$ & $13 \cdot 5 \pm 2 \cdot 3$ & $15 \cdot 1 \pm 1 \cdot 9$ & $19 \cdot 5 \pm 2 \cdot 1^{\text {** }}$ \\
\hline Fat free mass gain $(\mathrm{g})$ & $7 \cdot 2 \pm 6 \cdot 3$ & $8 \cdot 9 \pm 8 \cdot 0$ & $18 \cdot 1 \pm 7 \cdot 5^{*}$ \\
\hline$\%$ body fat & $18 \cdot 0 \pm 4 \cdot 9$ & $17 \cdot 2 \pm 4 \cdot 2$ & $14 \cdot 5 \pm 3 \cdot 9$ \\
\hline Plasma IGF-I (ng/ml) & $729 \pm 75$ & $777 \pm 39$ & $842 \pm 50^{* *}$ \\
\hline
\end{tabular}


repetitive administration of vehicle, and $6 \mathrm{mg} / \mathrm{kg}$ and $20 \mathrm{mg} / \mathrm{kg} \mathrm{SM}-130686$ per day were $32.3 \mathrm{~g}, 32.3 \mathrm{~g}$ and $34.1 \mathrm{~g}$ respectively. These data suggest that repetitive administration of SM-130686 also increases body protein. The food intake of rats given $20 \mathrm{mg} / \mathrm{kg} \mathrm{SM}-130686$ per day $(7.6 \mathrm{~g} / 100 \mathrm{~g}$ body weight per day) was not significantly different from rats given vehicle $(6.9 \mathrm{~g} / 100 \mathrm{~g}$ body weight per day). Compared with ghrelin and other GHSs, the action of SM-130686 may be closer to GH itself and more advantageous for the treatment of GH deficiency patients without deteriorating body composition or inducing obesity.

The reason why SM-130686 acts differently from ghrelin still remains unknown. We have demonstrated that the GH-releasing activity of SM-130686 was less potent $(52 \pm 12 \%)$ than ghrelin in rat pituitary cells, whereas SM-130686 has almost the same binding affinity as ghrelin $(0.25 \mathrm{nM}$ in Bednarek et al. 2000). These data indicate that SM-130686 might be a partial agonist for the GHS receptor, which may be one of the reasons for the difference between SM-130686 and ghrelin. Further studies will also be needed to unveil the mechanism of the action of SM-130686 in the endocrine system.

In summary, SM-130686 enhanced GH release from rat pituitary cells, possibly through a GHS receptor, and stimulated GH secretion both in anesthetized and conscious rats. Repetitive administration of SM130686 significantly increased fat free mass gain in addition to body weight gain in normal female rats. Taken together, this indicates that repetitive SM-130686 treatment has an anabolic effect similar to repetitive $\mathrm{GH}$ treatment.

\section{Acknowledgements}

We wish to thank Mr T Tokunaga, Mr E W Hume and Mr K Okazaki for their contribution and Ms N OkaharaMitsuhata for her technical assistance.

\section{References}

Azain MJ, Roberts TJ, Martin RJ \& Kasser TR 1995 Comparison of daily versus continuous administration of somatotropin on growth rate, feed intake, and body composition in intact female rats. Journal of Animal Sciences 73 1019-1029.

Bednarek MA, Feighner SD, Pong SS, McKee KK, Hreniuk DL, Silva MV, Warren VA, Howard AD, Van der Ploeg LHY \& Heck JV 2000 Structure-function studies on the new growth hormonereleasing peptide, ghrelin: minimal sequence of ghrelin necessary for activation of growth hormone secretagogue receptor 1a. Journal of Medicinal Chemistry 43 4370-4376.

Bowers CY, Momany FA, Reynolds GA \& Hong A 1984 On the in vitro and in vivo activity of a new synthetic hexapeptide that acts on the pituitary to specifically release growth hormone. Endocrinology 114 1537-1545.

Bowers CY, Alster DK \& Frentz JM 1992 The growth hormonereleasing activity of a synthetic hexapeptide in normal men and short statured children after oral administration. Journal of Clinical Endocrinology and Metabolism 74 292-298.

Camanni F, Ghigo E \& Arvat E 1998 Growth hormone-releasing peptides and their analogs. Frontiers in Neuroendocrinology 19 47-72.

Chapman IM, Bach MA, Cauter EV, Farmer M, Krupa D, Taylor AM, Schilling LM, Cole KY, Skiles EH, Pezzoli SS, Hartman ML, Veldhuis JD, Gormley GJ \& Thorner MO 1996 Stimulation of the growth hormone $(\mathrm{GH})$-insulin-like growth factor I axis by daily oral administration of a GH secretagogue (MK-677) in healthy elderly subjects. Journal of Clinical Endocrinology and Metabolism $\mathbf{8 1}$ 4249-4257.

Cheng K, Wei L, Chaung LY, Chan WWS, Butler B \& Smith RG 1997 Inhibition of L-692,429-stimulated rat growth hormone release by a weak substance P antagonist: L-756,867. Journal of Endocrinology 152 155-158.

Dieguez C \& Casanueva FF 2000 Ghrelin: a step forward in the understanding of somatotroph cell function and growth regulation. European Journal of Endocrinology 142 413-417.

Frohman LA, Downs TR \& Chomczynski P 1992 Regulation of growth hormone secretion. Frontiers in Neuroendocrinology 13 344-405.

Guan XM, Yu H, Palyha OC, McKee KK, Feighner SD, Sirinathsinghji DJS, Smith RG, Van der Ploeg LHT \& Howard AD 1997 Distribution of mRNA encoding the growth hormone secretagogue receptor in brain and peripheral tissues. Molecular Brain Research 48 23-29.

Hansen SB, Raun K, Nielsen KK, Johansen BP, Hansen KT, Peschke B, Lau J, Andersen HP \& Ankersen M 1999 Pharmacological characterisation of a new oral GH secretagogue, NN703. European Journal of Endocrinology 141 180-189.

Hartman ML, Farello G, Pezzoli SS \& Thorner MO 1992 Oral administration of growth hormone $(\mathrm{GH})$-releasing peptide stimulates GH secretion in normal men. Journal of Clinical Endocrinology and Metabolism 74 1378-1384.

Ho KY, Evans WS, Blizzard RM, Veldhuis JD, Merriam GR, Samojlik E, Furlanetto R, Rogol AD, Kaiser DL \& Thorner MO 1987 Effect of sex and age on the 24-hour profile of growth hormone secretion in man: importance of endogenous estradiol concentrations. Journal of Clinical Endocrinology and Metabolism 64 $51-58$.

Howard AD, Feighner SD, Cully DF, Arena JP, Liberator PA, Rosenblum CI, Hamelin M, Hreniuk DL, Palyha OC, Anderson J, Paress PS, Diaz C, Chou M, Liu KK, McKee KK, Pong SS, Chaung LY, Elbrecht A, Dashkevicz M, Heavens R, Rigby M, Sirinathsinghji DJS, Dean DC, Melillo DG, Patchett AA, Nargund R, Griffin PR, DeMartino JA, Gupta SK, Schaeffer JM, Smith RG \& Van der Ploeg LHT 1996 A receptor in pituitary and hypothalamus that functions in growth hormone release. Science $\mathbf{2 7 3}$ 974-977.

Iranmanesh A, Lizarralde G \& Veldhuis JD 1991 Age and relative adiposity are specific negative determinants of the frequency and amplitude of growth hormone $(\mathrm{GH})$ secretory bursts and the half-life of endogenous GH in healthy men. Journal of Clinical Endocrinology and Metabolism 73 1081-1088.

Kojima M, Hosoda H, Date Y, Nakazato M, Matsuo H \& Kangawa K 1999 Ghrelin is a growth-hormone-releasing acylated peptide from stomach. Nature 402 656-660.

Locke W, Kirgis HD, Bowers CY \& Abdoh AA 1995 Intracerebroventricular growth-hormone-releasing peptide-6 stimulates eating without affecting plasma growth hormone responses in rats. Life Sciences 56 1347-1352.

McDowell RS, Elias KA, Stanley MS, Burdick DJ, Burnier JP, Chan KS, Fairbrother WJ, Hammonds RG, Ingle GS, Jacobsen NE, Mortensen DL, Rawson TE, Won WB, Clark RG \& Somer TC 1995 Growth hormone secretagogues: characterization, efficacy, and minimal bioactive conformation. PNAS 92 11165-11169. 
Møller N, Jørgensen JO, Møller J, Ørskov L, Ovesen P, Schmitz O, Christiansen JS \& Ørskov H 1995 Metabolic effects of growth hormone in humans. Metabolism 44 33-36.

Morbach CA \& Brans YW 1992 Determination of body composition in growing rats by total body electrical conductivity. Journal of Pediatric Gastroenterology and Nutrition 14 283-292.

Müller EE, Locatelli V \& Cocchi D 1999 Neuroendocrine control of growth hormone secretion. Physiological Reviews 79 511-607.

Okada K, Ishii S, Minami S, Sugihara H, Shibasaki T \& Wakabayashi I 1996 Intracerebroventricular administration of the growth hormonereleasing peptide KP-102 increases food intake in free-feeding rats. Endocrinology 137 5155-5158.

Patchett AA, Nargund RP, Tata JR, Chen MH, Barakat KJ, Johnston DBR, Cheng K, Chan WWS, Butler B, Hickey G, Jacks T, Schleim K, Pong SS, Chaung LYP, Chen HY, Frazier E, Leung KH, Chiu SHL \& Smith RG 1995 Design and biological activities of L-163,191 (MK-0677): a potent, orally active growth hormone secretagogue. PNAS 92 7001-7005.

Rudman D 1985 Growth hormone, body composition, and aging. Journal of the American Geriatrics Society 33 800-807.
Tokunaga T, Hume WE, Umezome T, Okazaki K, Ueki Y, Kumagai K, Hourai S, Nagamine J, Seki H, Taiji M, Noguchi H \& Nagata R 2001 Oxindole derivatives as orally active potent growth hormone secretagogues. Journal of Medicinal Chemistry (In Press).

Tschöp M, Smiley DL \& Heiman ML 2000 Ghrelin induces adiposity in rodents. Nature 407 908-913.

Walker RF, Codd EE, Barone FC, Nelson AH, Goodwin T \& Campbell SA 1990 Oral activity of the growth hormone releasing peptide His-D-Trp-Ala-Trp-D-Phe-Lys- $\mathrm{NH}_{2}$ in rats, dogs and monkeys. Life Sciences 47 29-36.

Williams DA 1972 The comparison of several dose levels with a zero dose control. Biometrics 28 519-531.

Zadik Z, Chalew SA, McCarter RJ Jr, Meistas M \& Kowarski AA 1985 The influence of age on the 24-hour integrated concentration of growth hormone in normal individuals. Journal of Clinical Endocrinology and Metabolism 60 513-516.

Received 3 May 2001

Accepted 28 August 2001 